\title{
Size and overlap of home range in a high density population of the Japanese field vole Microtus montebelli
}

\author{
Kohtaro URAYAMA
}

\begin{abstract}
Urayama K. 1995. Size and overlap of home range in a high density population of the Japanese field vole Microtus montebelli. Acta Theriologica 40: 249-256.

Relationships of size and overlap of home range with the population density in a flood plain population of Microtus montebelli (Milne-Edwards, 1872) with high density were examined from April to December 1993 using mark-recapture method. Population density in the study area was reached 280 males/ha and 236 females/ha in summer. Although reproductively active voles were present throughout this study, more than half of females underwent reproductively resting period in summer. Main breeding seasons were spring and autumn when the density was relatively low. While the home range size of adult males did not decrease in summer when the population density was higher than other seasons, that of adult females was significantly smaller in summer than in spring or autumn. In summer, males showed significantly larger degree of home range overlap than in spring or autumn, while home ranges of females overlapped little throughout this study. These results differed from those of the previous studies on this species, possibly due to much higher density in mountainous populations.
\end{abstract}

Department of Biology, Faculty of Science, Ibaraki University, Mito 310, Japan

Key words: Microtus montebelli, home range, population density, spacing behaviour

\section{Introduction}

Field studies on the home range in the microtine rodents including genus Microtus so far carried out showed that the home range size was, in general, negatively correlated with the population density (Getz 1961, Ostfeld 1986, Erlinge et al. 1990). Batzil (1968) reported, on the other hand, that the home range size was independent of the population density in M. californicus, for which Ostfeld (1986) suggested negative relationship between them. Beside the population density, the social system that animals practice seems to affect the size and distributional pattern of the home range in Microtus (Madison 1980, Ostfeld et al. 1985, Getz and Hofmann 1986, Ostfeld 1986, Heske 1987). Subsequently behaviour relating to the home range would differ between sexes.

The Japanese field vole Microtus montebelli (Milne-Edwards, 1872) is endemic to Japan and lives in various habitats including plantation, paddy field and flood plain (Kaneko 1975). Its breeding phenology and population structure have been studied by using snap-traps (Abe 1974, Kaneko 1976, Saito et al. 1980, Kimura et 
al. 1980). Its population density is usually low in mountainous area (Kanamori and Tanaka 1968, Arai and Shiraishi 1982), while often reaches much higher density in flood plain populations (eg $1120 \mathrm{ind} / \mathrm{ha}$, Kitahara 1980; $313 \mathrm{ind} / \mathrm{ha}$, K. Urayama, unpubl.). Relationship between the home range size and the population density in $M$. montebelli has been studied in mountainous populations with relatively low density (Arai and Shiraishi 1982). Yet, little has been known about the home range in flood plain populations with high density.

The present study was designed to examine the relationship between traits relating to the home range and the population density in a flood plain population of $M$. montebelli. The mode of spacing behaviour is also discussed based on the analysis of the overlapping pattern of home ranges.

\section{Methods}

\section{Study area}

Field studies were conducted on a $200 \mathrm{~m}$ wide and $1.5 \mathrm{~km}$ long flood plain of Kuji River, Oomiya $\left(36^{\circ} 32^{\prime} \mathrm{N}, 140^{\circ} 19^{\prime} \mathrm{E}\right)$, Ibaraki Prefecture, central Japan. This study area was dominated by the perennial grass Phragmites communis, and the perennial forb Solidago altissima. The annual forb Cayratia japonica was scattered throughout the study area.

\section{Trapping procedures}

Field studies were conducted in 12 trapping-periods running from April to December 1993 (ie 1 to 4 April, 23 to 26 April, 6 to 9 May, 25 to 28 May, 10 to 13 June, 1 to 4 July, 23 to 29 July, 9 to 13 August, 19 to 22 September, 10 to 13 October, 3 to 7 November, and 29 November to 2 December; the trapping of late July was interrupted by bad weather and was performed on 23 to 24 and 28 to 29 July).

During each trapping-period, animals were caught using Sherman live-traps baited with sunflower seeds. A total of 90 trap stations spaced at $7 \mathrm{~m}$ interval were set on the flood plain to form $56 \times 63 \mathrm{~m}^{2}$ open study grid, which was located $50 \mathrm{~m}$ from the bank. A single trap was placed at each trap station in the first four (April to May) and the last trapping-periods (December), and two traps were used during the remaining periods (June to November). Traps were checked every eight hours. All voles caught were recorded for the trap position, sexed, weighed (to the nearest $0.5 \mathrm{~g}$ with a spring scale), checked for reproductive condition (for males: testes scrotal or non-scrotal; for females: vagina perforate or non-perforate, lactation tissue small or large, and embryos present or absent) and marked individually by toe-clipping.

\section{Demographic analysis}

Population density was estimated for each trapping-period using Jolly-Seber method. With reference to the reproductive conditions, voles were classified into three age classes according to their body weight. As most breeding voles indicated with testes scrotal for males and perforated vagina for females were heavier than $20 \mathrm{~g}$, individuals that were heavier than $20 \mathrm{~g}$ were considered as potentially reproductive voles. Individuals weighting less than $20 \mathrm{~g}$ were considered as "juvenile". "Subadult" and "adult" were individuals of which body weight was 20-30 g and more than $30 \mathrm{~g}$, respectively: a half of individuals weighted $20-30 \mathrm{~g}$ (subadults) was not in reproductive condition and they were considered to be on sexually maturing process. 
Home range analysis

In the analysis of the home range, only adults and subadults were considered. Home ranges were determined by the minimum area polygon method for voles that were caught more than twice in each trapping-period, and their areas $\left(\mathrm{m}^{2}\right)$ were calculated. Data for individuals which were caught at peripheral trap stations were excluded from the analysis, because such individuals may have had home ranges that extended outside the study grid, which caused underestimations of home range sizes. As the home range of some voles were represented by lines, the degree of intra-sexual overlaps of the home range is expressed as the following six categories instead of absolute values on percents of home range areas overlapped: (A) none of the home range area of a given vole is exclusive to the individual, (B) less than $50 \%$ of the home range area of a given vole is exclusive to the individual, (C) the home range of a given vole is overlapped with those of others in less than $50 \%$ of the area, (D) the home range of a given vole is adjoining with those of others on the side edge(s), (E) the home range of a given vole is adjoining with those of others only at the point(s), and (F) the home range of a given vole is without contact of those of others.

\section{Results}

Demography

A total of 4695 captures of 476 individuals of M. montebelli were obtained in this study. This corresponded to $90.3 \%$ of captures of all small mammals throughout the present study. Other animals captured were Apodemus speciosus (9.7\%) and Crocidura dsinezumi $(0.1 \%)$.

Population densities in both sexes were relatively low in the early spring (69 males/ha, 104 females/ha) and increased toward the summer, reaching a maximum in August in males (280/ha) and late July in females (236/ha). Then the density declined to 55 males/ha in December and 88 females/ha in late November (Fig. 1). In the further analysis of the relationship between the population density and the home range, three seasonal blocks, each comprising three trapping-periods in each season, are defined as follows: "spring" consists of trapping-periods in April and early May, "summer" is in July and August, and "autumn" is in October through early December.

Fig. 1. Seasonal change of the population density (ind/ha) of males (solid circles) and females (open circles) in Microtus montebelli.

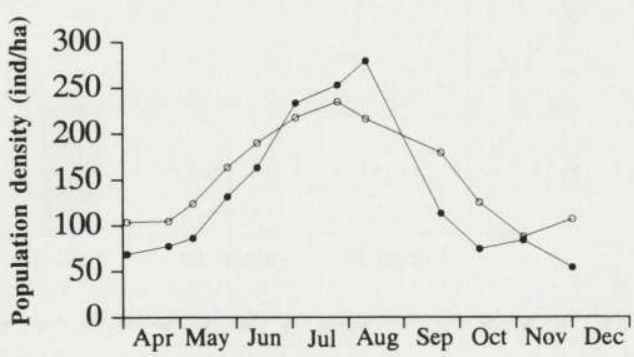

Month 
Although juvenile voles $(\leq 20 \mathrm{~g})$ were not discovered in early April, they started to appear in late April and were continuously present until early winter. This suggest that the breeding in this population had already begun by the commencement of the field research in April. All the adult males (>30 g) were in reproductively active condition throughout the study period (Fig. 2). In the summer, the half of subadult males ( $30 \mathrm{~g} \geq$ weight $>20 \mathrm{~g}$ ) which seemed to have been born
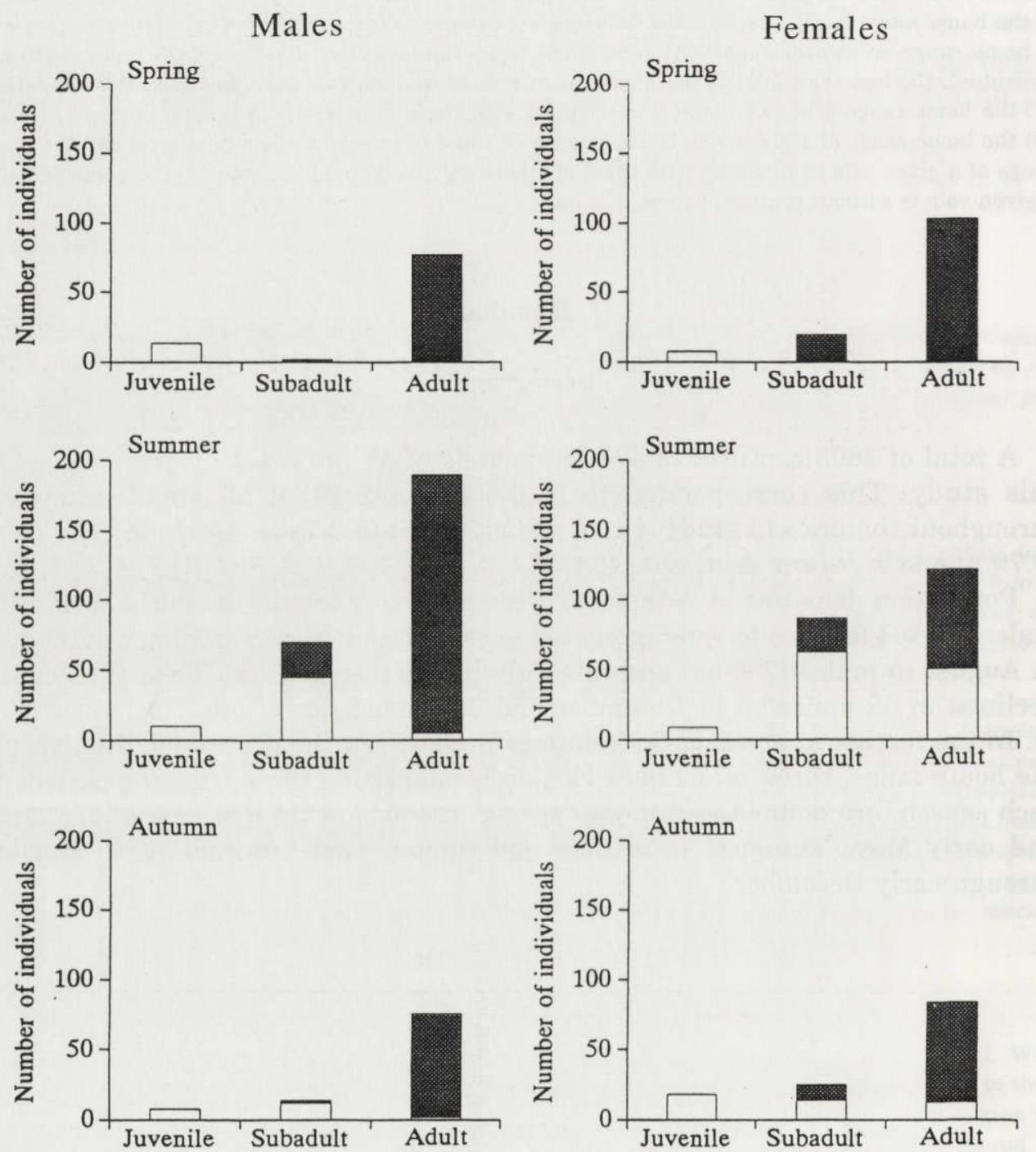

Fig. 2. Seasonal change of the demography in a flood plain population of Microtus montebelli. Solid bars - individuals in reproductive states, open bars - in non-reproductive states. Adult: weight $>30$ g, subadult: $30 \mathrm{~g} \geq$ weight $>20 \mathrm{~g}$, and juvenile: weight $\leq 20 \mathrm{~g}$. Spring - early April to early May, summer - early July to August, autumn - October to December. 
in the spring of the year were reproductively inactive. On the other hand, most of adult females and a part of subadult females were reproductively active in the spring and the autumn, but more than half individuals of adult and subadult females underwent a reproductively inactive period in the summer (Fig. 2).

\section{Home range}

Based on the data for home ranges with polygonal shapes, the mean of home range area of males tended to be larger than that of females throughout the present study except early May (Fig. 3) and differences were statistically significant at the level of $p<0.05$ in late May to October except early July $(p=0.08)$ and September $(p=0.10)$ (Mann-Whitney $U$-test). The home range areas (mean $\pm \mathrm{SE}$ )

Fig. 3. Seasonal change of the home range area $\left(\mathrm{m}^{2}\right)$ for males (solid circles) and females (open circles) in Microtus montebelli. Vertical bars show standard errors (SE).

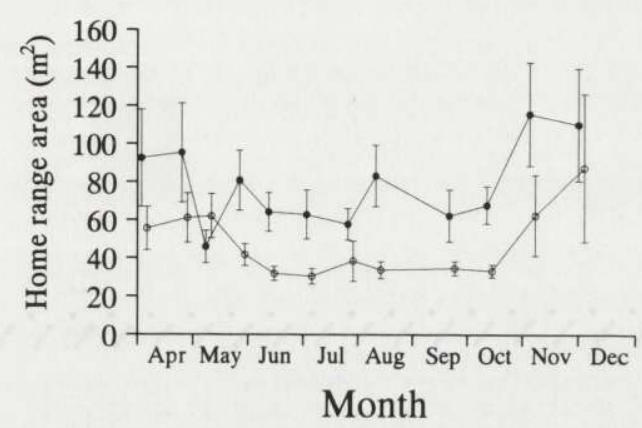

were not significantly different among "spring" $\left(79.2 \pm 13.1 \mathrm{~m}^{2}, n=26\right)$, "summer" $\left(69.7 \pm 8.0 \mathrm{~m}^{2}, n=70\right)$ and "autumn" $\left(94.7 \pm 12.7 \mathrm{~m}^{2}, n=22\right)$ for males (Kruskal-Wallis test, $p>0.05$ ). Range areas of females, on the other hand, were significantly smaller in "summer" $\left(35.0 \pm 4.5 \mathrm{~m}^{2}, n=35\right)$ than in "spring" (60.1 $\left.\pm 7.0 \mathrm{~m}^{2}, n=42\right)$ or "autumn" $\left(54.7 \pm 11.4 \mathrm{~m}^{2}, n=30\right)$ (Mann-Whitney $U$-test, $p$ $<0.05$ in both comparisons).

There was little overlap between the females' home ranges throughout the study period (Fig. 4). The same tendency appeared in males during spring and autumn, but in the summer the home range of males overlapped largely (Fig. 4). There were no statistically significant differences in the frequency distribution of the degree of the intra-sexual home range overlaps between sexes in spring and autumn (Kolomogorov-Simirnov two-sample test, $p>0.05$ in both comparisons, Fig. 4), while in summer significantly different and the home range for males largely overlapped intra-sexually (Kolomogorov-Simirnov two-sample test, $p<0.001$, Fig. 4). 
Fig. 4. Degree of the home range overlap for males (solid bars) and females (open bars) in spring (early April to early May), summer (early July to August) and autumn (October to December). Categories: A $-100 \%$ overlapping, B $50-100 \%$ overlapping, $\mathrm{C}$ - overlapping in less than $50 \%, \mathrm{D}$ - adjoining on side(s), E - adjoining at point(s), F - without contact.
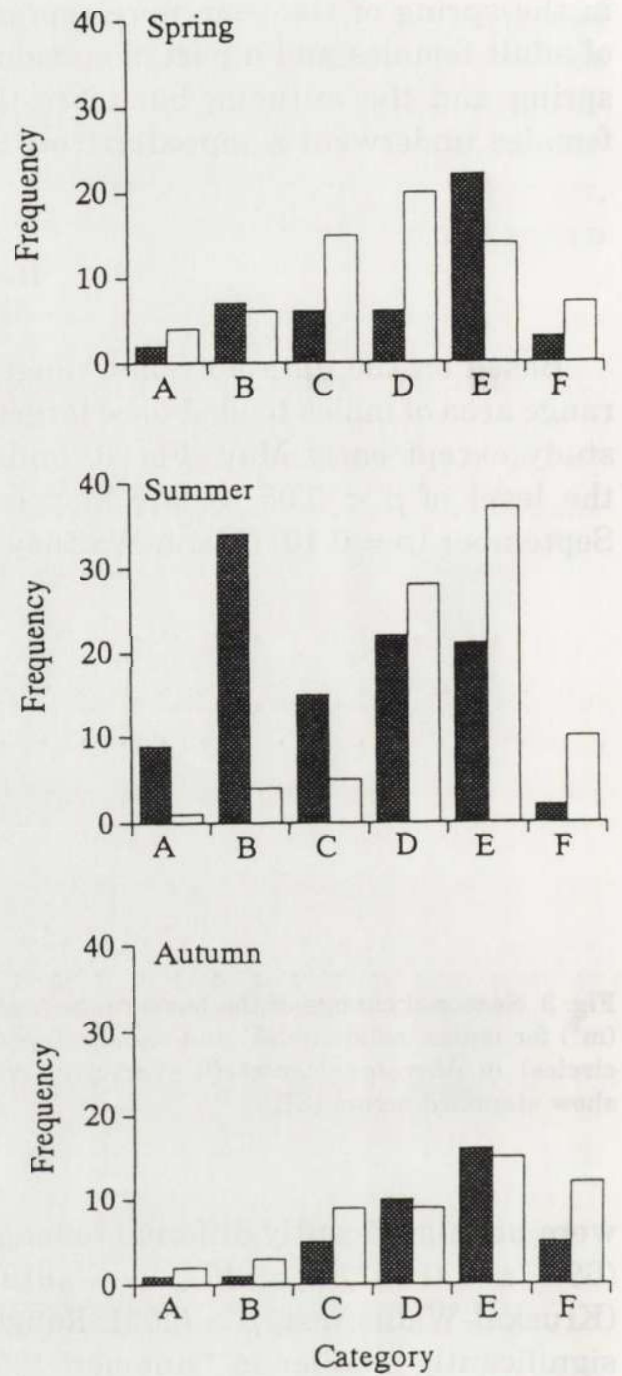

\section{Discussion}

The fact that the early-spring population lacked juveniles suggests that the voles were reproductively inactive in winter in the studied population. Although more than half of adult and subadult females was reproductively inactive in the summer, the rest of adult females and the most of adult males in the summer were reproductively active. This differs from those of the other studied populations of $M$. montebelli, in which both sexes bred in spring and autumn and underwent 
a reproductively inactive period in summer (Abe 1974, Kaneko 1976, Kimura et al. 1980). In this study, adult males that overwintered had already been reproductively active in spring and continued to be active until early winter. On the other hand, most of adult females bred in the spring and the autumn, and a half of them underwent the reproductively resting period in the summer. The spring-born males and females (ie subadults in summer) may have reached reproductive maturity in autumn. The reasons for such a difference in reproductive activities between adult males and females are not yet clear. One possible explanation is that the high population density has a negative influence on reproductive conditions of females, as suggested in Clethrionomys rufocanus bedfordiae (Saitoh 1981).

Kanamori and Tanaka (1968) noted that the home range size of $M$. montebelli decreased in both sexes as the density increased. Arai and Shiraishi (1982) showed that the home range sizes of males became larger at lower density, while the home range sizes of females were constant regardless of the population density. In this study, on the other hand, the home range size of males was not influenced by the change of the population density, while those of females became smaller in the summer when the population density was higher than the spring and autumn. Similar tendencies have been reported for Microtus townsendii (Taitt et al. 1981), M. californicus (Ostfeld 1986) and Clethrionomys rufocanus (Ims 1987) in which adult females reduced their home range size at the high population density, when the population densities were experimentally manipulated by food addition.

The degree of home range overlap of males in the studied population increased in the summer when the density was high, while that of females tended to be low in the summer despite the high population density. Such an increase of the home range overlap of males under high population density has been reported in $M$. californicus (Ostfeld et al. 1985) and C. rufocanus (Ims 1987).

In Microtus species, the overlap of home range is often a function of current social system that they employ. For example, in $M$. californicus, adult males have exclusive home ranges, while home range of adult females extensively overlap intra-sexually (Heske 1986, Ostfeld 1986). In contrast, home ranges of adult males of $M$. pennsylvanicus overlap extensively and females are considered to be territorial (Madison 1980, Ostfeld 1988). In M. ochrogaster, a family group defends its territory against other family groups (Getz and Hofmann 1986). Results on the seasonal change of home range sizes in this study suggested that, female home ranges in the present $M$. montebelli are overdispersed, while those of males are overlapping. Detailed comparisons of individual reproductive success among populations with different densities may shed light on the factors regulating habitat-associated reproductive activities in M. montebelli.

Acknowledgments: I thank R. S. Ostfeld, R. Adams-Manson and J. Kojima for critical reading of earlier drafts of the manuscript, and $\mathrm{H}$. Morino and $\mathrm{H}$. Tamura for constant guidance throughout the present study. I am also grateful to anonymous reviewers for valuable comments on the manuscript. Many thanks are due to H. Hosoda and J. Kojima for their help in the field research. 


\section{References}

Abe T. 1974. An analysis of age structure and reproductive activity of Microtus montebelli population based on year trapping data. Japanese Journal of applied Entomology and Zoology 18: 21-27. [In Japanese with English synopsis]

Arai S. and Shiraishi S. 1982. Population ecology of the Japanese field vole (Microtus montebelli) in Kyushu. I. Changes in population size and home range. Science bulletin of the Faculty of Agriculture, Kyushu University 36: 89-99. [In Japanese with English summary]

Batzil G. O. 1968. Dispersion patterns of mice in California annual grassland. Journal of Mammalogy 49: 239-250.

Erlinge S., Hoogenboom I., Nelson J. and Sandell M. 1990. Density-related home-range size and overlap in adult field voles (Microtus agrestis) in southern Sweden. Journal of Mammalogy 71: 597-603.

Getz L. L. 1961. Home ranges, territoriality, and movement of the meadow vole. Journal of Mammalogy 42: 24-36.

Getz L. L. and Hofmann J. E. 1986. Social organization in free-living prairie voles, Microtus ochrogaster. Behavioural Ecology and Sociobiology 18: 275-282.

Heske E. J. 1987. Spatial structuring and dispersal in a high density population of the California vole Microtus californicus. Holarctic Ecology 10: 137-148.

Ims R. A. 1987. Responses in spatial organization and behaviour to manipulations of the food resource in the vole Clethrionomys rufocanus. Journal of Animal Ecology 56: 585-596.

Kanamori M. and Tanaka R. 1968. Studies on population ecology of the vole, Microtus montebelli, in mountain grasslands of Sugadaira and its adjacent areas. I. Results of research on five populations in 1966-1967. Bulletin of the Sugadaira Biological Laboratory 2: 17-39. [In Japanese with English summary]

Kaneko Y. 1975. Mammals of Japan (12): Order Rodentia, Genus Microtus. Honyurui Kagaku 30: 3-26. [In Japanese]

Kaneko Y. 1976. Reproduction of Japanese field voles, Microtus montebelli (Milne-Edwards), at Iwakura, Kyoto. Japanese Journal of Ecology 26: 107-114.

Kimura Y., Saito T. and Hachiya T. 1980. On the breeding activity of the Japanese field voles, Microtus montebelli, at Mizuhara in Fukushima City. Science reports of the Faculty of Education, Fukushima University 30: 33-40. [In Japanese with English abstract]

Kitahara E. 1980. Notes on ecological respects of high dense Microtus population. Journal of the Mammalogical Society of Japan 8: 144-147. [In Japanese with English abstract]

Madison D. M. 1980. Space use and social structure in meadow voles, Microtus pennsylvanicus. Behavioural Ecology and Sociobiology 7: 65-71.

Ostfeld R. S. 1986. Territoriality and mating system of California voles. Journal of Animal Ecology 55: 691-706.

Ostfeld R. S., Lidicker W. Z., Jr and Heske E. J. 1985. The relationship between habitat heterogeneity, space use, and demography in a population of California voles. Oikos 45: 433-442.

Ostfeld R. S., Pugh S. R., Seamon J. O. and Tamarin R. H. 1988. Space use and reproductive success in a population of meadow vole. Journal of Animal Ecology 57: 385-394.

Saito T., Machida K., Inoue S. and Takahashi M. 1980. Reproductive activity of Microtus montebelli at Okegawa City in Saitama Prefecture. Journal of the Mammalogical Society of Japan 8: 122-128. [In Japanese with English abstract]

Saitoh T. 1981. Control of female maturation in high density populations of the red-backed vole, Clethrionomys rufocanus bedfordiae. Journal of Animal Ecology 50: 70-87.

Taitt M. J., Gipps J. H. W., Krebs C. J. and Dundjerski Z. 1981. The effect of extra food and cover on declining populations of Microtus townsendii. Canadian Journal of Zoology 59: 1593-1599.

Received 14 March 1995, accepted 12 July 1995. 